\title{
The Influence of MOOCs on the Reform and Development of English Foreign Language Teaching in China
}

\author{
Huanhuan Ren ${ }^{1, a}$, Chi Ma ${ }^{2, b}$ \\ ${ }^{1}$ Teaching and Research Institute of Foreign Languages, Bohai University, Jinzhou, 121013, China \\ ${ }^{2}$ Jinzhou Institute of Forestry Research, Jinzhou Forestry Bureau, Jinzhou, 121013, China \\ arenhuanhuan2014@163.com, ${ }^{\mathrm{b}}$ machi2014 @tom.com
}

Keywords: MOOC; Reform; English Language Teaching; China

\begin{abstract}
MOOCs are a disruptive trend changing how education is delivered and funded throughout the world, and there's no question that MOOCs have made people reconsider the future of higher education with respect to the intersection of education and technology. It's evident that traditional English foreign language teaching is not conductive to desirable learning outcomes in China and much things should be worked on for a better change. It's suggested that the influence of MOOCs on the development of English foreign language teaching in China be denoted in three dimensions, i.e. promoting reform awareness and actions, impacting on teacher professional development and enhancing strategic alliances with multiple partners, so as to create a climate that maximizes English language learning under MOOC background. It's hoped that this research provides a useful reference for future English foreign language education among college students.
\end{abstract}

\section{Introduction}

MOOCs are a disruptive trend changing how education is delivered and funded throughout the world, and it's found that instructors who are moving toward MOOCs often feel the impact of it. What implications do MOOCs have for learners seeking to study English as a foreign language in China? Will MOOCs reshape the English foreign language education landscape within the years to come? This research describes several ways we predict that MOOC platforms will impact the development of English foreign language teaching in China based on a review of definition of MOOC, types of MOOC, challenges of MOOC, and discussion on the problem and reform of English foreign language education in China, so as to create a climate that maximizes English language learning under MOOC background. This paper is a summary of this research work, which hopefully provides a useful reference for future English foreign language education among college students.

\section{The Problem and Reform of English Foreign Language On-campus Education in China}

\section{The Emergence of MOOCs across the Globe}

Definition of MOOC. Massive open online course, abbreviated to MOOC, is an online course aimed at unlimited participation and open access via the web[1]. The term MOOC was coined in 2008 by Dave Cormier of the University of Prince Edward Island in response to a course called Connectivism and Connective Knowledge (also known as CCK08)[2]. As the name implies, MOOC features large-scale global participation, open access and web-based class environment. That is, MOOCS can be accessed by anyone anywhere as long as they have an internet connection, are open to everyone without entry qualifications, and offer a complete course experience online for free. Thereby, it's no surprising in the fact that a MOOC generally carries no fees, no prerequisites (other than Internet access and interest), no predefined expectations for participation, and no formal accreditation[3]. Right now, many universities scramble to join in the next big thing, include Stanford, Harvard, MIT, the University of Pennsylvania, etc. Among universities pioneers, Massachusetts Institute of Technology (MIT) quickly became the thought leader of open online 
education. Concerned about the commercialization of online education, MIT, in 2012, made commitment to keep all course materials available to the world online for no cost created the not-for-profit MITx[4]. MOOCs emerged as a popular mode of learning in 2012, and a plethora of education media declared 2012 the year of the MOOC, as several well-financed providers, associated with top universities, emerged. It's suggested by mainstream news that this new type of course revolutionize the model of higher education and change the world of education[5].

Types of MOOC. There appear to be two patterns of MOOC and they were coined by Stephen Downes, co-creator of the first cMOOC to hit the web launched in 2008, i.e. cMOOC and xMOOC [6]. cMOOC emphasizes the connectivist philosophy which centers the power of networking with other individuals. Milligan shared the same view, claiming that the core concepts of cMOOC are connectivism, knowledge construction, the interactive learning and self-regulated learning, among other things[7]. It's found in Ravenscroft's work that connectivist MOOCs better support collaborative dialogue and knowledge building[8]. Despite it, several top universities - such as Harvard, MIT, and Stanford - have begun to offer xMOOCs in a somewhat different format, and the world of xMOOCs is expanding to cover more and more topics every day[9]. xMOOCs resemble much more traditional course structure, with emphasis on knowledge transmission and replication. That is, they are a combination of a pre-recorded video lecture with quizzes, tests, or other assessments. Learners are required to complete the course by viewing videos in a planned way, doing exercises systematically and participating in an interactive way. Comparatively speaking, as George Siemens concluded succinctly, "cMOOCs focus on knowledge creation and generation, whereas xMOOCs focus on knowledge duplication.[10]" The fact is that xMOOCs are not better or worse than a cMOOC, just different[11]. cMOOCs and xMOOCs are found incompatible and not being blended both pedagogically and philosophically, but learners can have freedom to bounce between structure and unstructured pathways based on personal interest[12].

Challenges of MOOC. Granted, it's a short history, but MOOCs have generated both high hopes and ample skepticism in high education circles. Many people have argued that MOOCs are not a big deal, just a more modern version of educational broadcasting, another example of the overblown hyperbole often surrounding technology, particularly in the USA[13]. It's also shared by some scholar in his work stating that MOOCs are the next logical step in two increasingly growing phenomena: online learning and open educational resources, and they are not conceptually as revolutionary as they seem[14]. The revolutionary potential of massive open online courses has been met with much skepticism, particularly in terms of the values behind them and possible detrimental consequences, the quality of online learning provided and whether it deserves credentialing[15]. Some also invite both practical and philosophical questions for the future of higher education: Will MOOCs reshape the higher education landscape in the second decade of the 21st century and beyond? Will they provide more value for institutions or translate to losses in tuition dollars? Will MOOCs mean more access to higher education for students around the world or will emerging for-profit models squeeze out the very students who could stand to benefit the most? Do MOOCs have the potential to overcome access challenges associated with prohibitive education costs in the U.S. and institutional barriers in developing countries? Or is the profit motive likely to breed fierce competition among education provider institutions that will extinguish the free MOOC movement? And what will become of pedagogy in the 21st century: Will professors become celebrities, salesmen, or get sidelined? [16] From above, we can say that there are severe difficulties and limitations for developing the knowledge and skills needed in a digital age through MOOCs.

\section{The Problem and Reform of English Foreign Language Education in China}

Problems of English Foreign Language in China. Statistics has shown that, more than 400 million people in China today, about a third of the total population, are involved in the learning of some foreign languages and especially the English language[17]. Learning English in China has become a real fad, and a plethora of researches and studies are devoted to the development of English foreign language learning. Then how do students in China learn English language? In the field of English language teaching there are countless textbooks, learning programs and curricula 
from which to choose, however, the traditional way of learning English in classroom is in large groups with the methods of memorizing and taking tests. The fact is this approach fails to yield desirable learning outcomes and few people seem to adequately meet the language needs of new Americans. It's easier for one to find a person who has put in much efforts in learning for so many years but still found in difficulty in communicating with native people in English. The problems rising from it seems to be that the traditional teaching methods put much stress on the scores in a variety of tests other than the proficiency and skills in English language of language learners. In brief, traditional language pedagogical approach is not conductive to desirable English learning outcomes and much things should be worked on for a better educational change in China.

Reform of English Foreign Language in China. With a view to keeping up with the new developments of higher education in China, deepening teaching reform, improving teaching quality, and meeting the needs of the country and society for qualified personnel in the new era, College English Curriculum Requirements, one requirement of which is to remold the existing unitary teacher-centered pattern of language teaching, was drawn up by Ministry of Education of the People's Republic of China in 2007[18]. Since then, the Requirements serves as the guidelines for English instruction to non-English major students in colleges and universities. In it, six aspects of college English curriculum are specified, consisting character and objectives of college English, teaching requirements, course design, teaching model, evaluation and teaching administration. It's suggested that "the extensive use of advanced information technology should be encouraged, computer- and Web-based courses should be developed, and students should be provided with favorable environment and facilities for language learning”[19]. Meanwhile, apart from top-down policy, bottom-up change from learners are also part of the holistic influence of advanced information technology on English pedagogical mode in China[20]. It seems that nothing is more common than learners utilizing the Internet and World Wide Web for obtaining target information content or connecting with other people, and it is no more new the overwhelming effect of new media on educational industry.

\section{The Influence of MOOCs on the Development of English Language Teaching in China}

MOOCs Promote Reform Awareness and Actions. It's claimed that nothing has more potential to enable us to reimagine higher education than the massive open online course[21]. We can see the impact of MOOCs on traditional on-campus education is profound. Thus, in what ways will MOOCs change the higher education landscape, especially pertaining to English foreign language students studying in China? It's inevitable that English foreign language teaching in China is supposed to take a deep reform. Firstly, despite the fact that it's not necessary to run a MOOC on English foreign language for every university or college in China, English foreign language instruction is doomed to move towards further development with advanced information technology. It's argued that the use of educational technology can result in a higher return on foreign language learning with audiovisual aids and autonomous learning schedule. Secondly, English foreign language instruction is directed at delivering personalized and tailored teaching. MOOCs enable students to demonstrate knowledge of the kinds of things they might be interested in, even beyond the traditional high school curriculum, so that students can personalize their learning experiences in English learning process. Lastly, English foreign language instruction is aimed at providing more opportunities for autonomous learning through MOOCs. Knowledge can be accessed anywhere and any place as long as they have an internet connection. All in all, the emerging and flourishing MOOCs give much insights into how to develop pedagogical strategies for English foreign language teaching in China, in hope of compensating for deficiencies in mainstream language pedagogy.

MOOCs Impact on Teacher Professional development. MOOCs change the role of professors and what it means to be a teacher in an era of online education. Firstly, new skills and responsibilities are supposed to be established among English language instructors with respect with the emergence of MOOCs. Differences between MOOCs and traditional face-to-face classes affect the preparation, presentation, and assessment of the material, teaching style and teaching knowledge and 
experiences. Teachers should receive training in advance of the course debut by being savvy at multimedia technologies and taking more responsibilities outside of school day. Secondly, big data gathered about the online actions of students collectively from the Internet are good for research studies on teacher development in future. As MOOC enrollments have climbed exponentially, much information can be given to teachers to develop course and create more effective learning experiences. Lastly, English language teachers are encouraged to be teamed up with colleagues, scholars or global partners in a move toward cooperative work. Open learning movement opens up opportunities for the more meaningful engagement and collaboration between people with some interests in professional development, enabling them perform better in teaching and learning. To sum up, with new models of online education are emerging as alternatives to traditional brick-and-mortar higher education institutions, professional development is continuing to be a perennial challenge for instructors.

MOOCs Enhance Strategic Alliances with Multiple Partners. Under the MOOC background, strategic alliances should be strengthened between industry, academia and the research community for better educational resources. Firstly, MOOCs are particularly relevant to software professionals in academia and industry because future researchers and practitioners will likely receive much of their education through MOOCs and associated digital learning methods and tools. Just as the scholar observes, online education is itself not a new phenomenon, the intersection of education technology and entrepreneurial ventures investing in education are changing the landscape of online education as we know it[22]. That is, MOOCs are dependent on the advancement of educational technologies to revolutionize access to higher education across the globe[23]. Secondly, a great deal of money is required to develop video and other course content in a MOOC and operate the platform. Universities that are spearheading online education efforts have allocated millions of dollars in support of MOOCs. It's found that a MOOC usually has one or more higher education colleges or schools behind it, and, in some cases, a for-profit company. Through collaborating with other universities, institution, corporations, or venture capitalists, funds or grants may be provided by them for MOOCs. Lastly, moving to MOOCs is a collaborative effort between many dedicated staff with expertise to generate a good pedagogical result. A significant number of staff are needed to contribute to a connected learning environment. It make sense to think about how we engaged our supporters to build dedicated communities of instructors and learners. In brief, through strategic alliances with multiple partners, MOOC providers are pursuing cooperation for expertise, capital, efforts from other fields so that they can be more successful in reaching and engaging local populations.

\section{Summary}

It's concurred that MOOCs have the potential to change the education landscape across the globe. The fact is evident that traditional English foreign language teaching is not conductive to desirable learning outcomes in China and much things should be worked on for a better change. It's suggested that the influence of MOOCs on the development of English foreign language teaching in China be denoted in three dimensions, i.e. promoting reform awareness and actions, impacting on teacher professional development and enhancing strategic alliances with multiple partners, so as to create a climate that maximizes English language learning under MOOC background. It's hoped that this research provides a useful reference for future English foreign language education among college students.

\section{Acknowledgements}

This work is part of the project of On Cultivating and Developing Liaoning Scientific Foreign Language Talents with View to Bourdieu' Theory, the project of On Establishing Generative Mechanism of EFL Autonomous Learning Behaviors and Strengthening Development of Learning Field in Ubiquitous Learning Space, and the project of On Constructing Mechanism and Strategies for College English Autonomous Learning Abilities via Mobile Multimedia. This research was 
supported by the fund of Liaoning Planning of Philosophy and Social Science (Project No. L16CYY001), the fund of Liaoning Provincial Federation Social Science Circles (Project No. 2017lslktyb-019), and the fund of the Thirteenth Five-Year Plan of Education Sciences of Liaoning Province (Project No. JG16DB013).

\section{References}

[1] Andreas M. Kaplan. Haenlein Michael. Higher education and the digital revolution: About MOOCs, SPOCs, social media, and the Cookie Monster. Business Horizons, Volume 59. 2016.

[2] Chris Parr. Mooc creators criticise courses' lack of creativity. Times Higher Education, 2013.

[3]Alexander McAuley, Bonnie Stewart, George Siemens and Dave Cormier. THE MOOC MODEL FOR DIGITAL PRACTICE. Retrieved from the information on http : // elearnspace.org /Articles/ MOOC_Final.pdf. 2010.

[4] MITx on edX (MOOCs), MIT Office of Digital Learning. Retrieved 2 May 2015.

[5]Tamar Lewin. Universities Abroad Join Partnerships on the Web. New York Times, March 2013.

[6] John Prpić,; Melton, James; Taeihagh, Araz; Anderson, Terry (16 December 2015). "MOOCs and crowdsourcing: Massive courses and massive resources". First Monday. 20(12).

[7] C. Milligan, A. Margaryan, A. Littlejohn. Patterns of engagement in massive open online courses. Journal of Online Learning with Technology (Special Issue on MOOCs)- Under Review. 2013 (5).

[8] Andrew Ravenscroft. Dialogue and Connectivism: A New Approach to Understanding and Promoting Dialogue-Rich Networked Learning. International Review of Research in Open and Distance Learning, March 2011.

[9] What is the Difference Between xMOOCs and cMOOCs? Retrieved from the information on http://blogs.onlineeducation.touro.edu/distinguishing-between-cmoocs-and-xmoocs/, august, 2013.

[10] George Siemens. MOOCs are really a platform. Elearnspace. Retrieved 2012-12-09.

[11]Debbie Morrison. The Ultimate Student Guide to xMOOCs and cMOOCs. Commentary, Credit Watch, Apr 22, 2013. Retrieved from the information on http : // moocnewsandreviews. Com /ultimate-guide-to-xmoocs-and-cmoocso / \# ixzz4W52uDzeX

[12] Multiple pathways: Blending xMOOCs \& cMOOCs. Retrieved from the information on http://www.elearnspace.org/blog/2014/05/06/multiple-pathways-blending-xmoocs-cmoocs/?utm_so urce=tuicool\&utm_medium=referral, may ,2014.

[13] Tony Grates. What is a MOOC? 2014. Retrieved from the information on http://www.tonybates.ca/2014/10/12/what-is-a-mooc/

[14] [15] Maha Bali. MOOC Pedagogy: Gleaning Good Practice from Existing MOOCs. MERLOT Journal of Online Learning and Teaching. Vol. 10, No. 1, March 2014.

[16] Raisa Belyavina. A MOOC Article a Day: Three Themes To Watch. Institute of International Education. January 22, 2013. Retrieved from the information on http : // www. iie. org/ Blog/ 2013 /January /MOOC -Themes-to-Watch\#.WH8qq0Jpx-U

[17] J. Flor Cruz, Wanna learn English, anyone? CNN.com, June 10, 2011.

[18] [19] Ministry of Education of the People's Republic of China, College English Curriculum Requirements. Beijing: Higher Education Press, 2007.

[20] Ren Huanhuan, Ma Chi. Development and Reform Research on College English Pedagogical 
Mode in New Media Context. Advances in Computer Science Research, 2016, volume 50, 2016.

[21] Thomas Friedland. Revolution hits the universities. New York Times, January 26, 2013.

[22][23] Raisa Belyavina. The MOOC Metamorphosis of Online Education. Education U S A, CONNECTIONS. MAY 2013. 